\title{
Returns from Indigenous Hunting in The Lowland Coastal Forests of West Papua, Benefits Threatened Wildlife Species
}

\author{
Freddy Pattiselanno ${ }^{1,2} *$, Johan F. Koibur ${ }^{2}$ \\ 'Faculty of Animal Science, Papua University, Jalan Gunung Salju Amban, Manokwari, Indonesia 98314 \\ ${ }^{2}$ Biodiversity Research Center, Papua University, Jalan Gunung Salju Amban, Manokwari, Indonesia 98314
}

Received February 14, 2018/Accepted April 17, 2018

\begin{abstract}
We conducted a study in eleven villages in the West Papuan Bird's Head Peninsula to determine hunting returns from indigenous hunting in lowland coastal forests. In each town three collaborative hunters were recruited and trained to complete an information sheet for each hunting trip whether or not they were successful, and if so, how many individuals per species were killed and their common names. The results indicated that hunting returns during seven months of observations were 301 animals comprising of timor deer, wild pig, dusky pademelon, grizzled tree kangaroo and common spotted cuscus. The most commonly hunted were two non-native species-wild pigs and deer with a total of 11,475 $\mathrm{kg}$ of dressed weight harvested and which we valued at IDR230,625,000 (US\$17,435). A lowland forest ecosystem along the coast provides suitable habitats for the largest animals occurring within the sampled villages, like deer and wild pig. Hunting those species-deer and wild pig may provide conservation benefits to native species. There was little evidence of hunting native species or those of conservation concern. From ecology perspective, prey species and hunting return across the lowland coastal forest of West Papua has introduced wildlife species occurring at degraded habitat. Economically, the number of species hunted within the sampled village areas is determined by the hunter's assessment of profitability. Deer and wild pig are targeted because they provide a large amount of meat for both subsistence and sale purposes.
\end{abstract}

Keywords: Indigenous hunting, prey species, lowland forest, West Papua

*Correspondence author, email:f.pattiselanno@ unipa.ac.id,ph.: +62-986-212156; fax: +62-986-211455

\section{Introduction}

Wildlife hunting is important for satisfying people's need for meat as a source of dietary protein, and is of economic value through the sale of bushmeat products to communities (Milner-Gulland et al. 2003), obtaining ingredients for human medicine and other traditional uses (Williamson 2002; Mockrin et al. 2005). Furthermore, wild animals are hunted to obtain trophies (skins, teeth, antlers, and horns) that are used as cultural artifacts or for personal adornment (Fa \& Brown 2009).

Various wildlife species are hunted in Africa and Neotropical areas ranging from the smaller and larger animals (Ráez-Luna 1995; Ntiamoa-Baidu 1997; Bakkar et al. 2002; Barnett 2002; Fa et al. 2002; Naranjo et al. 2004). In Sarawak, rural hunters were recorded to regularly take 26 mammal, 12 bird, and 5 reptile species (Bennett et al. 1995). In Papua New Guinea (PNG) many different species are hunted across a variety of ethnic groups, in local PNG dialect, including the $s a b$ (large mammals), the honez (small mammals), the sort (birds). Other game species also hunted include jiya (frogs), wen (fish) and the occasional large reptile, notably burun (pythons), and they are all acha (edible fauna) (Dwyer 1983; Sillitoe 2001; Johnson et al. 2004;
Mack \& West 2005). In Indonesian New Guinea (Papua and West Papua Provinces), various species are hunted such as, deer, and wild pig (Pattiselanno 2003), cuscus-Phalangeridae (Pattiselanno \& Koibur 2008); cassowary, bandicoots, flying foxes and tree kangaroos (Pangau-Adam etal. 2012).

Previous research has demonstrated a relationship between prey species and harvest rate. For example, annual wild meat harvest in Sarawak (Malaysia) was estimated 23,500 tonnes, in the Brazilian Amazon at 67,000-164,000 tonnes and in Central Africa at 1-3.4 million tonnes (MilnerGulland et al. 2003). Even higher take-off rates were reported from the Neotropical and Afrotropical where annually over 5 million tonnes of wild mammal meat supplies meals for millions of people (Fa et al. 2002). Whereas, these are estimated for entire regions, for conservation purposes it is important to know what take-off rates are reported locally. These rates can be very high. They also found that there is a correlation between sales and wild meat species. In the southern Laos market town of That Luang, some 8,000-10,000 mammals, 6,000-7,000 birds, and 3,000-4,000 reptiles were traded annually (Bennett \& Rao 2002). In one market in North Sulawesi, Indonesia, 
$50,000-75,000$ forest rats and $>15,000$ bats were traded annually, in addition to large numbers of native pigs and other species (Clayton \& Milner-Gulland 2000). Such hunting rates are often unsustainable and result in local wildlife extinctions (Bennett et al. 2002; Robinson \& Bennett 2004; Corlett 2007).

In Langowan market of Minahasa, North Sulawesi with majority of christians, wild pigs accounted for $67 \%$ of animals sold each week in the 19931995 market survey (Milner-Gulland \& Clayton 2002). Pigs also provided 58\% of the total large game harvest by weight in traditional hunting by the Wana of upland Central Sulawesi (Alvard 2000). Luskin et al. (2014) found that in 2011 over 7,500 wild boars were sold in Jambi city on Sumatera alone.

In Genyem and Nimbokrang town of Papua deer and wild pig were sold for US\$50 - per the whole animal (PangauAdam et al. 2012). Hunters in Jambi city of Sumatera earned $\sim$ IDR5,000 on average for each kilogram of dressing with approximately $3,550 \mathrm{~kg}$ per dressed carcass (Luskin et al. 2014).

Hunting prey is intimately linked to many cultures throughout the world's tropical forests. Therefore, although hunting may capture a variety of wild animal species, some species may be favored over others. Certain species are less preferred because of sociocultural or religious barriers (Njiforti 1996; Fa et al. 2002). Preferences for different wildlife species are usually influenced by economic activity, access to domestic meat, ethnic origin, geographical isolation, local wildlife availability and the biological attributes of species that are hunted (Naranjo et al. 2004). In addition, other factors influence prey preference, such as the social, cultural and political characteristics of the ethnic groups that hunt (Fa et al. 2002).

Indigenous hunting in Papua contributes significantly to local livelihood (Pattiselanno 2006). In this study, we determine the hunting returns from indigenous hunting which will allow us to calculate the harvest rate of hunted species and to predict the ongoing effect of hunting on prey species targeted by hunters. We conducted our studies in lowland coastal forests where indigenous hunting is commonly performed by local communities (Pattiselanno \& Lubis 2014; Pattiselanno \& Mambai 2015). This study also wishes to measure the impact of hunting on the lowland coastal forests at the Bird's Head Peninsula in West Papua.

\section{Methods}

Our study sites were eleven villages located across the Bird's Head Peninsula (Figure 1). In the Abun District the villages were Waibem, Wau, Warmandi, and Saubeba with Karon as the major ethnic group across villages. In the Amberbaken District, we surveyed the Arupi, Wekari, Saukorem, Wasarak, Wefiani, Samfarmun, and Imbuan where the Mpurs are the majority ethnic group. In both districts, there were also mixed Papuans group (Biak, Serui, Wondama, and Sorong) and non-Papuans from Java, Sulawesi, Maluku, and other parts of Indonesia.

In each village, three collaborative hunters were recruited and trained to complete an information sheet from each hunting trip. This information included whether or not they were successful, and if so, how many individuals per species were killed and the common names of these species (Fusari \& Carpaneto 2000; Carpaneto \& Fusari 2006). The

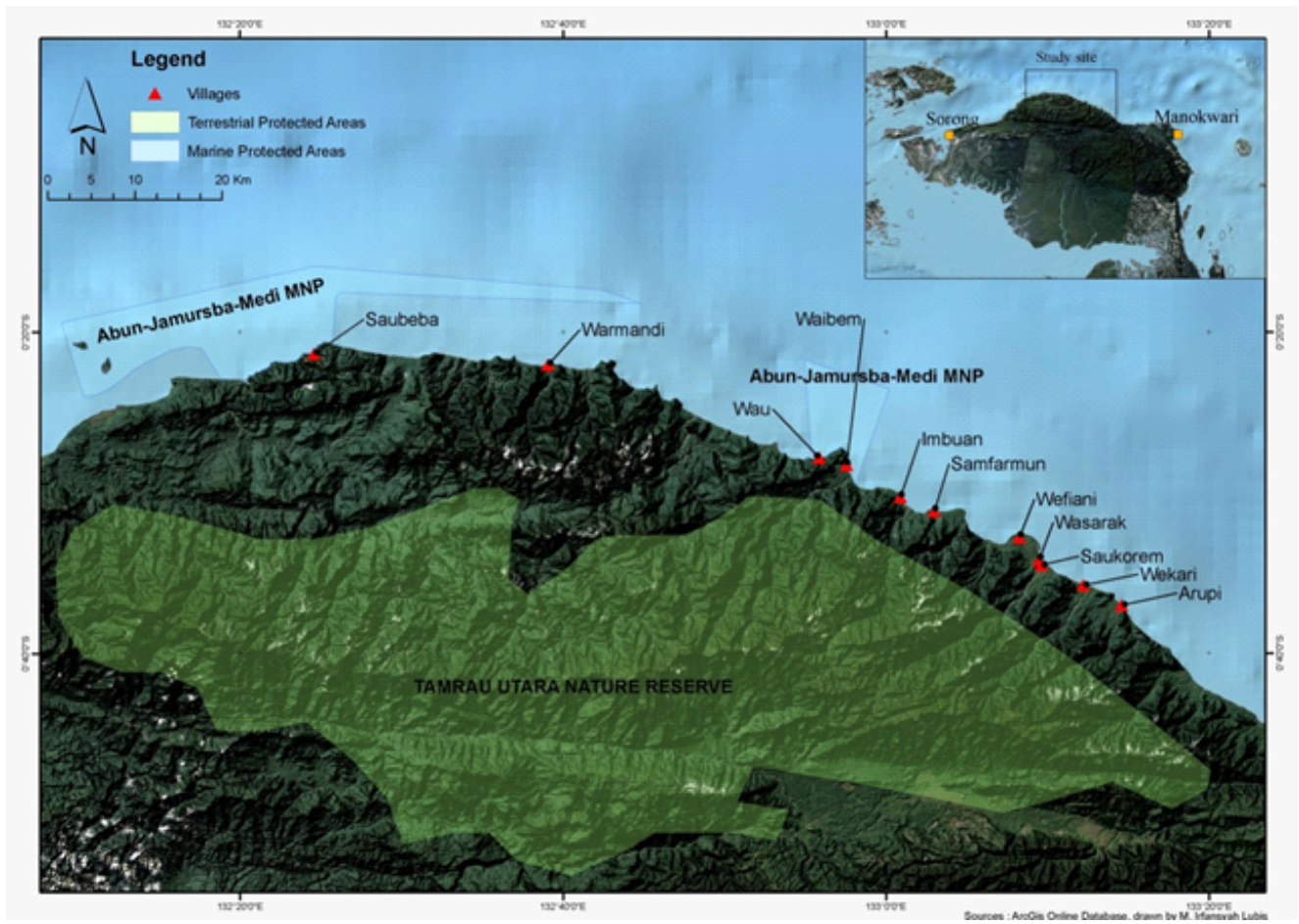

Figure 1 Eleven villages-our study sites along the coast of the Bird's Head Peninsula. 
information was triangulated by having informal discussions and by interviewing key respondents such as other (noncollaborated) hunters and community leaders during that time, so we had similar information from each collaborated hunter.

\section{Results and discussion}

Prey species and hunting returns Different hunting preys were acknowledged in the latest hunting excursions during informal discussions with hunters prior to data collections. Species hunted across the study villages were similar and included timor deer (Cervus timorensis), wild pig (Sus scrofa), dusky padamelon (Thylogale brunii), grizzled tree kangaroo (Dendrolagus inustus), common spotted cuscus (Spilocuscus maculatus), spiny bandicoots (Echymipera kalubu), northern cassowary (Cassuarius unappendiculatus), papuan hornbil (Rhyticeros plicatus) and pinon imperial-pigeon (Ducula pinon). Two species that were most commonly hunted were two non-native speciesild pigs and deer. This also similar to the 301 animals-hunting returns reported by 33 focal hunters during seven-month observations (Table 1 ).

Related to the fact that deer and wild pig dominated hunting returns, hunters acknowledged that hunting was primarily for selling at markets to obtain extra money. However, some parts of carcasses including head, bones, legs and intestines, were kepts for family consumption. Therefore, although hunters sold carcasses to dealers they still had other parts for consumption.

Larger numbers of wild pig and deer hunted, not only indicated the abundance of this species in the study sites (Pattiselanno \& Arobaya 2009; Pattiselanno et al. 2011), but also confirmed that the practice of hunting was primarily for trade and consumption (Pattiselanno 2006; Pattiselanno \& Lubis 2014; Pattiselanno \& Mambai 2015). In most cases, bushmeat markets sell ungulates, such as deer and wild pig. These species are the most important source of income where trade has been documented (Robinson \& Bennett 2000; Fa \& Brown 2009). According to Smith (2005), a preference for many animals as edible game is dependent on body mass, ease of preparation, taste and cultural attitudes towards different species. Other cultural mediating factors such as familiarity, tradition and prestige, also drove the demand for bushmeat (Schenk et al. 2006).

The economic value of hunting Throughout the observed period a total $11,475 \mathrm{~kg}$ of dressed weight of deer and wild pig from 275 individuals were harvested with the local price, of IDR $25,000 \mathrm{~kg}^{-1}$ (equivalent to US\$1.89 $\mathrm{kg}^{-1}$ ) for venison and IDR15,000 (or US\$1.13) for pork. The total hunting take was valued at IDR230,625,000 (US\$17,435). In addition to pigs and deer, 26 individuals of native species with a total of $99 \mathrm{~kg}$ dressed weight were harvested but they were consumed locally, not sold. In West Papua, although the hunting target varies from one site to another, wild pig and deer are the most commonly hunted species in all study sites, because they are widely distributed (Pattiselanno 2006; 2012). Likewise, in Jayapura region of north-east Papua the main hunting targets were the introduced wild pig and rusa deer, apparently because, each individual has significant amount of dressed carcass that benefit hunters (PangauAdam etal.2012).

Pigs are an extremely important source of hunted meat for traditional groups in Southeast Asia (Caldecott 1988) and contribute significantly to the traditional economies across New Guinea, including Indonesian New Guinea (Dwyer 1983). Differently, in other parts of Asian, hunting of indigenous wildlife is mostly conducted to supply the needs of traditional medicine (Corlett 2007). For that reason, the preferred prey of hunters in northern Myanmar are tigers, bears and pangolins (Rao et al. 2005) rather than food species like deer, pigs, primates, and porcupines found in the same area.

Our data expresses that hunting for sale is also essential to support local livelihoods within the study villages. In this study, hunting returns may only contribute to the local economy, but it is an important small economic activity in the study sites. In this study, hunting is not a primary source of income. Monthly income varied among households, although it was not solely obtained from agriculture. Income of hunters across the villages was the median of IDR1,200,000 (equivalent to US\$99.13).

In contrast to studies from the Africa and South American, estimates of the national value of the bushmeat trade range from US\$42-205 million across countries in West and Central Africa (Davies 2002). In the Congo Basin

Table 1 Seven months of hunting returns reported by 33 collaborating hunters in study villages

\begin{tabular}{|c|c|c|c|c|c|}
\hline Scientific name & Common name & $\begin{array}{c}\text { Average } \\
\text { weight } \\
\left(\mathrm{kg}^{-1}\right)\end{array}$ & $\begin{array}{l}\text { Total } \\
\text { individual }\end{array}$ & $\begin{array}{l}\text { Dressed } \\
\text { weight }^{2}\end{array}$ & 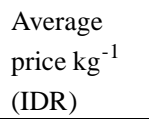 \\
\hline Rusatimorensis & Timor deer & 65 & 150 & 5,850 & 25,000 \\
\hline Sus scrofa & Wild pig & 75 & 125 & 5,625 & 15,000 \\
\hline Thylogale brunii & Dusky pademelon & 4 & 9 & 21.6 & - \\
\hline Dendrolagus inustus & Grizzled tree kangaroo & 12 & 7 & 50.4 & - \\
\hline Spilocuscus maculatus & Common spotted cuscus & 4.5 & 10 & 27 & - \\
\hline Total & & 301 & & 11,574 & $230,625,000$ \\
\hline
\end{tabular}


the scale of meat trade reached about 5 million tonnes year ${ }^{-1}$ or US\$ millions annually (Wilkie \& Carpenter 1999). In the Amazon Basin the value exceeds US\$175 million year ${ }^{-1}$, and in Coté d'Ivoire it was estimated to be US\$200 million (Rao \& Mc Gowan 2002).

We found that venison-meat from deer, was usually transported to the nearest district where the meat was sold to non-papuan natives, mostly muslim at the transmigrant settlements. In this study, the harvest rates of particular species were also more likely to be influenced by market demand and consumer preference for particular bushmeat and the market value was promising. Similar to other studies around the world (Lindsey et al. 2013; Luskin et al. 2014; van Vliet et al. 2015), it was clear that trading was conducted in the rural sites in these study villages and the meat was transported into the market in town.

The implication of hunting on prey species In this study, a lowland forest ecosystem along the coast provides suitable habitats for the largest animals occurred within the sampled villages like deer and wild pig. Firstly, in terms of forest management, changing of forest landscapes into agricultural plantations and converting into infrastructures have changed wildlife composition that economically benefited local hunters. This study found that in particular site, hunting was conducted in secondary forest and crop land to protect crop damages from a wild pig.

The people we studied were mainly hunting introduced species in converted habitats and there was little evidence of hunting of native species or those of conservation concern. Previous studies (Pattiselanno \& Koibur 2008; Pattiselanno \& Arobaya 2013) obtained similar results with our findings. Our data recorded only 26 individual or $9 \%$ of native species brought home during the seven months of observation (Table 1). Hunting on both introduced species-deer and wild pig may have to benefit native species in terms of conservation.

Secondly, along with the provincial development across the landscape, forest conversion into roads and other infrastructures including commercial agricultural, logging concessions and other purposes together with increased in human populations threaten the native species habitat and reduced the populations. Parallel to the biophysical such as road access and forest conversions and demographic changes, wildlife communities (e.g. species composition including native species and relative abundance) are also changing within the new landscapes (Fitzherbert et al. 2008). Our survey suggests that overall hunting is not exerting pressure on native species.

\section{Conclusions}

The overall range of species taken is determined by the hunter's assessment of profitability. Deer and wild pig are targeted because they provide a large amount of meat for both subsistence and sale purposes. Our findings indicate commercial hunting to support local livelihoods is currently trending within the study villages. In this study, hunting returns may only contribute to the local economy, but it is an important small economic activity in the study sites.
Ecologically, prey species and hunting return across the lowland coastal forest of West Papua was introduced wildlife species occurred at converted habitat. This study also shows that hunting is conducted in secondary forest and crop land to protect crop damages from wildlife species.

\section{Acknowledgement}

We acknowledged financial support from the Skyrail Foundation, Rufford Foundation Grant 10569-1, and Seed Fund for Research and Training (SFRT) Program of SEARCA Grant GCS11-4203 for the first author.

\section{References}

Albrechtsen L, Fa JE, Barry B, MacDonald DW. 2006. Contrasts in availability and consumption of animal protein in Bioko Island, West Africa: The role of bushmeat. Environmental Conservation 32(4):340-348. https://doi.org/10.1017/S037689 2906002694.

Alvard MS. 2000. The impact of traditional subsistence hunting and trapping on prey populations: data from Wana horticulturalists of upland Central Sulawesi, Indonesia. In: Hunting for Sustainability in Tropical Forests. Robinson JG, Bennett EL, editors. New York: Columbia University Press.

Auzel P, Wilkie DS. 2000. Wildlife use in Northern Congo: Hunting in a commercial logging concession. In: Hunting for Sustainability in Tropical Forests. Robinson JG, Bennett EL, editors. New York: Columbia University Press.

Bakkar M, Ampadu-Agyei O, Adomako E, Ham R. 2002. Bushmeat utilization, human livelihoods and conservation of large mammals in West Africa. In: Links between Biodiversity Conservation, Livelihoods, and Food Security: The sustainable use of wild species for meat. Mainka SA, Trivedi M, editors. IUCN, Gland, Switzerland and Cambridge, UK.

Barnett R. 2002. Wild meat utilization in the east and southern Africa region. In: Links between Biodiversity Conservation, Livelihoods and Food Security: The sustainable use of wild species for meat. Mainka SA, Trivedi M, editors. IUCN, Gland, Switzerland and Cambridge, UK: IUCN, Gland.

Bennett EL, Milner-Gulland EJ, Bakarr M, Eves, HE, Robinson JG, Wilkie DS. 2002. Hunting the world's wildlife to extinction. Oryx 36:328-329.

Bennett EL, Nyaoi J, Sompud J. 1995. A Conservation Management Study of Wildlife Hunting in Sabah and Sarawak. Report on the Completion of Fieldwork. New York: Wildlife Conservation Society.

Bennett EL, Rao M. 2002. Wild meat consumption in Asian tropical forest countries: Is this a glimpse of the future for Africa? In: Links between Biodiversity 
Conservation, Livelihoods, and Food Security: The sustainable use of wild species for meat. Mainka SA, Trivedi M, editors. IUCN, Gland Switzerland and Cambridge, UK.

Caldecott J. 1988. Hunting and wildlife management in Sarawak. IUCN, Gland, Switzerland and Cambridge England.

Carpaneto GM, Fusari A. 2006. Subsistence hunting and bushmeat exploitation in central-western Tanzania. Biodiversity and Conservation 9:1571-1585.

Clayton LM, Milner-Gulland EJ. 2000. The trade in wildlife in North Sulawesi, Indonesia. In: Hunting for Sustainability in Tropical Forests. Robinson JG, Bennett EL, editors. New York: Columbia University Press.

Corlett RT. 2007. The impact of hunting on the mammalian fauna of tropical Asian forests. Biotropica 39(3):292-303.

Davies G. 2002. Bushmeat and international development. Conservation Biology 16(3):588-589.

Dwyer PD. 1983. Etolo hunting performances and energetics. Human Ecology 11:145-174.

Fa JE, Peres CA, Meeuwig J. 2002.Bushmeat exploitation in tropical forests: an intercontinental comparison. Conservation Biology 16:232-237.

Fa JE, Brown D. 2009. Impacts of hunting on mammals in African tropical moist forests: A review and synthesis. Mammal Review 39(4):231-264.

Fitzherbert, EB, Struebig MJ, Morel A, Danielsen F, Bruhl CA, Donald F, Phalan B. 2008. How will oil palm expansion affect biodiversity? Trends in Ecology \& Evolution 23:538-545.

Flannery TF. 1995. Mammals of New Guinea. Reed Books, Australia.

Fusari A, Carpaneto GM. 2000. Subsistence hunting and conservation issues in the game reserve of Gile, Mozambique. Biodiversity and Conservation $15: 2477-2495$.

Johnson A, Bino R, Igag P. 2004. A preliminary evaluation of the sustainability of cassowary (Aves: Casuariidae) capture and trade in Papua New Guinea. Animal Conservation 7:129-137.

Luskin MS, Christina ED, Kelley LC, Potts MD. 2014. Modern hunting practices and wild meat trade in the oil plantation-dominated landscape of Sumatra. Human Ecology 42:35-45. https://doi.org/10.1007/c10745013-906-8.
Mack AL, West P. 2005. Ten thousand tonnes of small animals: Wildlife consumption in Papua New Guinea, a vital resource in need of management. Resource Management in Asia-Pacific Working Paper No. 61, Resource Management in Asia-Pacific Program, C a n berra: A N U. Retrieved from http://rspas.anu.edu.au/papers/rmap/Wpapers/rmap_w p61.pdf.

Milner-Gulland EJ, Clayton L. 2002. The trade in babirusas and wild pigs in North Sulawesi, Indonesia. Ecological Economics 42:165-183.

Milner-Gulland EJ, Bennett EL, Abernethy K, Bakarr M, Bodmer R, Brashares J, Cowlishaw G, Elkan P, Heather P, Peres C, Roberts P, Robinson J, Rowcliffe M \& Wilkie D. 2003. Wild meat: the bigger picture. Trends in Ecology and Evolution 18(7):351-357.

Mockrin MH, Bennett EL, La Bruna DT. 2005. Wildlife farming: A viable alternative to hunting in tropical forests? WCS Working Paper No. 23.

Naranjo EJ, Guerra MM, Bodmer RE, Bolaños JE. 2004. Subsistence hunting by three ethnic groups of the Lacandon Forest, Mexico. Journal of Ethnobiology 24(2):233-253.

Njiforti HL. 1996. Preferences and present demand for bushmeat in north Cameroon: Some implications for wildlife conservation. Environmental Conservation 23(2):149-155.

Ntiamoa-Baidu Y. 1997. Wildlife and food security in Africa.FAO Conservation Guide 33.Food and Agriculture Organization of the United Nations, Rome.

Pangau-Adam M, Noske R, Muehlenberg M. 2012. Wildmeat or bushmeat? Subsistence hunting and commercial harvesting in Papua (West New Guinea), Indonesia. Human Ecology 40:611-621.

Pattiselanno F, Arobaya AYS. 2009. Grazing habitat of the rusa deer (Cervustimorensis) in the upland Kebar, Manokwari. Biodiversitas 10(3):134-138.

Pattiselanno F, Arobaya AYS. 2013. The global center of marine biodiversity in peril. The Jakarta Post 31 July 2013.

Pattiselanno F, Koibur JF. 2008. Cuscus (Phalangeridae) hunting by Biak Ethnic Group in Surrounding North Biak Strict Nature Reserve, Papua. Hayati Journal of Bioscience 15(3):130-134.

Pattiselanno F, Lubis MI. 2014. Hunting at the Abun Regional Marine Protected Areas: A link between wild meat and food security. HAYATI Journal of Biosciences 21(4):180-186. https://doi.org/10.4308/hjb.21.4.180.

Pattiselanno F, Mambai B. 2015. Commercialization of 
hunting in the Bird's Head Peninsula. Traffic Bulletin 27(1): 45 .

Pattiselanno F, Randa SY, Iyai DA, Baaka A. 2011. Indigenous pig management in West Papua (Highland Vs Coastal sites). Suiform Soundings 11(1): 40-43.

Pattiselanno F. 2003. The wildlife value; example from West Papua, Indonesia. Tigerpaper 30(1):27-29.

Pattiselanno F. 2006. The wildlife hunting in Papua. Biota 11(1):59-61.

Pattiselanno F. 2012. Deer (Cervustimorensis) at the highland Kebar West Papua, Indonesia (Deer utilization in Papua). Germany: LambertAcademic Publishing.

Ráez-Luna EF. 1995. Hunting large primates and conservation of the Neotropical rain forests. Oryx 29(1):43-48.

Rao M, Myint T, Zaw T, Htun S. 2005. Hunting pattern in tropical forests adjoining the Hkakaborazi National Park, north Myanmar. Oryx 39(3):292-300.

Rao M, McGowan PJK. 2002. Wild-meat use, food security, livelihoods, and conservation. Conservation Biology 16(3):580-583.
Robinson JG, Bennett EL. 2000. Hunting for sustainability in Tropical Forests. New York: Columbia University Press.

Schenk M, Effa NM, Starkey M, Wilkie D, Abernethy K, Telfer P, Godoy R, Treves A. 2006. Why people eat bushmeat: Results from two-choice, taste test in Gabon, Central Africa. Human Ecology 34(3):433-445. https://doi.org/10.1007/s10745-006-9025-1.

Sillitoe P. 2001. Hunting for Conservation in the Papua New Guinea Highlands. Ethnos 66(3):365-393.

Smith DA. 2005. Garden Game: Shifting Cultivation, Indigenous Hunting and Wildlife Ecology in Western Panama. Human Ecology 33(4):505-537. https://doi.org/10.1007/s10745-005-5157-Y.

Wilkie DS, Carpenter JF.1999. Bushmeat hunting in the Congo Basin: an assessment of impacts and options for mitigation. Biodiversity and Conservation 8:927-955.

Williamson D. 2002.Wild meat, food security and forest conservation. In: Links between biodiversity conservation, livelihoods and food Security: The sustainable use of wild species for meat. Mainka SA, Trivedi M, editors. IUCN, Gland, Switzerland and Cambridge, UK. 